Int. J. Dev. Biol. 55: 757-762

doi: $10.1387 / \mathrm{ijdb} .113414 \mathrm{cw}$

\title{
Remodeling mechanisms of the mammary gland during involution
}

\author{
CHRISTINE J. WATSON* and PETER A. KREUZALER \\ Department of Pathology, University of Cambridge, Tennis Court Road, Cambridge, UK
}

\begin{abstract}
The process of post-lactational regression, or involution, of the mammary gland is a complex event characterised by extensive death of the secretory epithelium coupled with remodeIling of the extracellular matrix and adipogenesis to regenerate the fat pad. Associated with these events is an inflammatory cascade and acute phase response. The critical signalling pathways that regulated involution have been defined and a wide variety of genes have been shown to modulate the various processes involved, including cell death, phagocytosis, tissue remodelling and innate immune response.
\end{abstract}

KEY WORDS: cell death, apoptosis, Stat, lysosome, inflammation

\section{Introduction}

The primary function of the mammary gland is to provide nutrition, in the form of milk, to newborn mammals. Milk also provides passive protection from infection and in higher mammals, suckling promotes bonding (Oftedal, 2002). However, this life-giving role has a flip side as the breast is highly susceptible to cancer (Bray et al., 2004). Although it has been established that an early fullterm pregnancy provides some protection from breast cancer (Albrektsen et al., 1994; Lambe et al., 1994), there is compelling epidemiological evidence that pregnancy increases the risk of breast cancer in the short term (Lambe et al., 1994) and more recently, experimental evidence has suggested that the process of postlactational regression provides a tumour promotional environment (McDaniel et al., 2006). In this article, I will review the process of post-lactational involution, the signalling pathways involved and the role of different cell types in this complex event.

The development of the mammary gland occurs in three distinct phases: during embryogenesis, puberty and pregnancy. A rudimentary structure is generated in the embryo and it is not until puberty that extensive ductal elongation occurs culminating in the filling of the fat pad with an extensively arbourised epithelium by about 8-10 weeks of age. In response to pregnancy, tertiary branching and formation of lobuloalveolar structures is initiated in concert with de-differentiation of the adipocytes in the fat pad. The mammary gland then becomes a milk-producing organ upon birth of the offspring and following their weaning, the now superfluous lobuloalveolar cells die in an exquisitely controlled process of cell death coupled with tissue remodelling and re-emergence of lipid- filled adipocytes. The gland is returned to an almost pre-pregnant state and this cycle of gestation, lactation and involution repeats itself with each successive pregnancy.

\section{The process of involution}

The process of involution is complex requiring not only the initiation of extensive cell death to remove the milk-producing epithelial cells but also the controlled influx of macrophages and other immune cell types to remove the dead cells, residual milk and debris. These events are coupled with breakdown of extracellullar matrix, remodelling of blood vessels and re-differentiation of adipocytes to regenerate the fad pad.

In the past decade, our understanding of the molecular and cellular events that underlie involution in the mouse mammary gland has greatly increased primarily due to investigations with genetically modified mice and global transcriptional profiling studies which have provided a detailed analysis of the first 4 - 6 days of involution. In most of these studies a synchronous involution is induced by either removal of pups at the peak of lactation or by milk stasis using teat sealing. Interestingly, involution takes place in two discrete phases called first phase and second phase. The first phase lasts for approximately 48 hours in the mouse and is reversible, while in the second phase a remodelling programme is initiated that returns the gland to a pre-pregnant state (Lund et al., 1996). It seems likely that this early reversibility is required to

Abbreviations used in this paper: LMP, lysosomal membrane permeabilisation; MMP, matrix metalloproteinase; ROS, reactive oxygen species.

\footnotetext{
*Address correspondence to: Christine J. Watson. Department of Pathology, University of Cambridge, Tennis Court Road, Cambridge CB2 10P, UK. Tel: +44-1223-33725. Fax: +44-1223-333346. e-mail: cjw53@cam.ac.uk; pak29@ cam.ac.uk - web: www.path.cam.ac.uk/ madgroup
} 
allow offspring to re-initiate lactation by suckling if required after a prolonged period away from the mother. Notably, in fur seals lactation can recommence after a period of three weeks while the mother is offshore feeding (Sharp et al., 2006). First phase involution is characterised by the appearance of shed, dying cells within the lumena of the alveoli which become expanded by the accumulation of milk. At this time, infiltration by neutrophils also occurs. Using teat-sealing in mice, it was demonstrated that the first phase is regulated by local factors and not by circulating hormones (Li et al., 1997; Marti et al., 1997).

In the second phase, cell death is accompanied by upregulation of matrix metalloproteinases (MMPs) which are important in the remodelling of the surrounding stroma which is accompanied by adipocyte refilling, influx of macrophages and active plasma kallikrein that regulates adipocyte differentiation and stromal remodelling (Lilla et al., 2009). This phase is dependent on circulating factors and can be halted by the administration of glucocorticoid (Feng et al., 1995; Lund et al., 1996), which may act through the maintenance of tight junctions (Zettl et al., 1992). MMP function is blocked in the first phase by expression of tissue inhibitors of metalloproteinases (TIMPs)(Green and Lund, 2005).

Transcriptional profiling data have further subdivided these two functional phases into four discrete transcriptional events (Clarkson et al., 2004; Stein et al., 2004), marked by four clusters of genes that have distinct temporal patterns of expression. A subset of genes is dramatically induced within 12 hours of forced involution with expression declining rapidly thereafter. This could suggest that a different mechanisms is triggering cell death in the first phase of involution than in the second. Whether there are four distinct phases to the involution process, rather than the two described morphologically, is not yet clear. Therefore, in any study of involution, it is important to consider these early signalling events and the fact that cell death appears to be a stochastic process. It is also essential to consider the nonepithelial cells of the gland, as both the adipocytes and the vasculature are dramatically modified during involution, and phagocytes (both professional and nonprofessional) are essential for clearing the gland of cell debris and milk components.

The essential signalling pathways that initiate involution have been identified using sophisticated genetic approaches. Although a considerable number of genes are implicated in cell death regulation during involution, many of these might be downstream components of these signalling pathways, and thus may have a minor role to play in the overall process. It is clear that involution is a highly complex process in which all aspects are tightly regulated. In this review we will consider in detail the mechanism and control of cell death and the role of the innate immune system in remodelling events.

\section{Cell death during involution - how is it initiated?}

Milk stasis seems to be the primary trigger of involution and cell death (Li et al., 1997). There have been several suggestions as to how milk stasis might initiate involution including mechanical stretch of the alveolar epithelium due to milk retention in the lumen (Quaglino et al., 2009) or the build up of secreted factors in the milk. The plasma membrane calcium-ATPase 2 (PMCA2), which transports $60-70 \%$ of milk calcium, is dramatically upregulated during lactation to be just as dramatically downregulated during involution. Recently, PMCA2 was shown to be regulated by changes in the shape of mammary epithelial cells (VanHouten et al., 2010). Furthermore, mice harbouring a null mutation in the Atp2b2 gene (encoding PMCA2) exhibited precocious cell death at day 18 of pregnancy and this was accompanied by activation of Stat3. It seems likely that secreted factors such as LIF (Kritikou et al., 2003; Schere-Levy et al., 2003), serotonin (Matsuda et al., 2004), and TGF $\beta$-3 (Nguyen and Pollard, 2000) are also important in inducing cell death as mice deficient for LIF exhibited delayed involution (Kritikou et al., 2003) while directed expression of TGF $\beta$-3 in the alveolar epithelium of lactating mice induced apoptosis without tissue remodelling. Serotonin suppresses $\beta$-casein gene expression and causes mammary alveoli to shrink.

A considerable number of genes have been implicated in involution. These are summarised in Table 1. Much of these data have been derived from genetically altered mice and the involution phenotypes are often subtle, suggesting that crosstalk between pathways is important. The most dramatic delay in involution is seen when the transcription factor Stat3 is conditionally deleted in mammary epithelium. Cell death and tissue remodelling are completely abrogated in the absence of Stat3 (Chapman et al., 1999) and the reversible phase of involution is extended until at least 6 days post forced involution (Humphreys et al., 2002). A number of

\section{TABLE 1}

\section{FACTORS THAT REGULATE INVOLUTION}

\begin{tabular}{|c|c|c|}
\hline Gene & Function & Method of assessment \\
\hline \multicolumn{3}{|c|}{ Factors that inhibit involution and/or cell death } \\
\hline IRF-1 & Transcription factor & Gene deletion \\
\hline Stat5 & Transcription factor & Overexpressing transgenic \\
\hline TIMP-3 & MMP inhibitor & Gene deletion \\
\hline SOCS-3 & Cytokine signalling regulator & Conditional gene deletion \\
\hline Akt & Serine/threonine kinase & Overexpressing transgenic \\
\hline Sim2s & Transcription factor & Overexpressing transgenic \\
\hline $\mathrm{Bcl} 2$ & Apoptosis regulator & Overexpressing transgenic \\
\hline Bcl-x & Apoptosis regulator & Conditional gene deletion \\
\hline IGF-I & Growth factor & Overexpressing transgenic \\
\hline IGF-II & Growth factor & Overexpressing transgenic \\
\hline JAK2 & Kinase & Constitutively active mutant \\
\hline \multicolumn{3}{|c|}{ Factors that promote involution and/or cell death } \\
\hline Stat3 & Transcription factor & Conditional gene deletion \\
\hline c/ebp $\delta$ & Transcription factor & Gene deletion \\
\hline $\mathrm{IKK} 2 / \beta$ & Regulatory kinase & Conditional gene deletion \\
\hline p53 & Transcription factor & Gene deletion \\
\hline PTEN & lipid phosphatase & Overexpressing transgenic \\
\hline IL-6 & Cytokine & Gene deletion \\
\hline LIF & Cytokine & Gene deletion \\
\hline FasL & Cytokine & Gene deletion \\
\hline IL-10 & Cytokine & Gene deletion \\
\hline Bax & Apoptosis regulator & Gene deletion \\
\hline Cathepsin L & Cysteine protease & Specific inhibitor \\
\hline ATF4 & Transcription factor & Overexpressing transgenic \\
\hline Smad3 & TGF- $\beta$ signalling mediator & Gene deletion \\
\hline IGFBP-5 & IGF inhibitor & Overexpressing transgenic \\
\hline$\alpha$-lactalbumin multimers & Milk protein & Culture studies \\
\hline Mnt & Transcriptional repressor & Conditional gene deletion \\
\hline \multicolumn{3}{|c|}{ Factors that affect remodeling and/or biosynthesis } \\
\hline plasmin & Serine protease & Gene deletion \\
\hline Mfge8 & Phagocytosis regulator & Gene deletion \\
\hline kallikrein & Plasminogen activator & Inhibitor studies \\
\hline MMP3 & protease & Gene deletion \\
\hline
\end{tabular}


genes that are regulated by Stat3, such as c-ebpu61540, OSMR and IGFBP-5, are also regulators of cell death and involution (Thangaraju et al., 2005). A similar delay is observed when the upstream regulator of the NF-KB pathways, IKK $\beta$, is conditionally deleted (Baxter et al., 2006) suggesting that crosstalk between these signalling pathways is required for the process of involution to occur and that each pathway is necessary, but neither is sufficient, to trigger cell death. Components of apoptosis pathways have also been implicated including death receptor ligands such as FasL (Song et al., 2000) which is important for apoptosis at $24 \mathrm{~h}$ involution and TRAIL, which is upregulated by IL-10 during involution (Sohn et al., 2001) in addition to members of the Bcl2 family of apoptosis regulators such as Bax, which promotes cell death as deletion of Bax results in a modest decrease in apoptosis in first phase and $\mathrm{Bcl} 2$, which promotes survival of the epithelium in a gain-of-function transgenic model (Schorr et al., 1999). Loss of the anti-apoptotic Bcl-xL accelerates involution (Walton et al., 2001). During second phase involution, cell death occurs alongside tissue remodelling and it is more difficult to discern delayed involution phenotypes. However, removal of dead cells and residual milk is critical for involution to proceed and subsequent successful lactation as reduced phagocytosis in the absence of the bridging molecule MFGE8 results in inflammation and tissue scarring and subsequent failed lactation (Atabai et al., 2005; Hanayama and Nagata, 2005).

\section{What is the mechanism of cell death during involution?}

Until recently, the mechanism responsible for the destruction of the secretory epithelium during involution was presumed to be apoptosis, a form of programmed cell death that occurs in all multicellular animals. The term apoptosis (Greek for 'falling leaves') was coined by Kerr, Wyllie and Currie in 1972 (Kerr et al., 1972). The genetics and biochemistry of apoptosis have been extensively studied (Danial and Korsmeyer, 2004). However, it is now apparent that there are multiple cell death pathways and as many as ten genetically programmed cell death pathways have been defined that occur in different situations and in response to diverse stimuli (Melino et al., 2005).

The morphology of the dying cells that are detached from the alveolar wall and shed into the lumen is not classically apoptotic (Fig. 1). Shed cells appear to be swollen, have two hypercondensed nuclei, and a complete lack of membrane blebbing. They show no features of entosis, a recently described form of programmed cell death that has been described in mammary epithelial cells in vitro (Overholtzer et al., 2007). Furthermore, TdT-mediated dUTP nick end labelled (TUNEL) positive cells could not be detected in the first $24 \mathrm{~h}$ of involution although these are apparent at 72 $\mathrm{h}$ involution. However, executioner caspases are still activated during involution and indeed cleavage of caspase 3 if often used as a measure of cell death during involution. Recently, the reason for this unusual morphology was discovered. Stat3 was shown to induce a lysosomal pathway of cell death (LM-PCD) that is independent of executioner caspases, which are dispensible for involution (Kreuzaler et al.). Interestingly, Stat3 upregulates the expression of the lysosomal enzymes cathepsin B and cathepsin $L$ while downregulating the expression of their endogenous inhibitor Spi2a. Cathepsins leak from the lysosomes during involution and initiate cell death, resulting in the shedding of cells into the lumen where caspases 3 and 6 are cleaved, probably in response to anoikis resulting from detachment from neighbouring alveolar cells. This was the first demonstration that a lysosomal pathway of cell death occurs in a normal physiological context in vivo. It will be interesting to determine whether other signalling pathways contribute to LM-PCD during involution. This discovery requires a re-appraisal of previous data on involution. Mediators of LMP are depicted in Fig. 2.

It is distinctly possible that macroautophagy also occurs during involution. This is a survival mechanism, usually initiated by cells during starvation to recycle cellular components (Kroemer and Levine, 2008). Autophagy would provide a mechanism that ensures the reversibility of first phase involution. To date, there is scant evidence of autophagy during involution although genetic models are now available and a definitive answer to this question may become available in the bear future. It is worth noting in this context that fully functional lysosomes are required for autophagy.

\section{How is the mammary gland remodelled during involu- tion?}

Although there is extensive cell death during involution, the architecture of the gland does not change notably during the first $48 \mathrm{~h}$. However, the switch to second phase triggers extensive remodelling resulting in removal of the remaining epithelium concomitantly with redifferentiation of adipocytes. This phase is marked by protease activity, which remodels the extracellular matrix. It is not clear what the trigger is for the switch to second

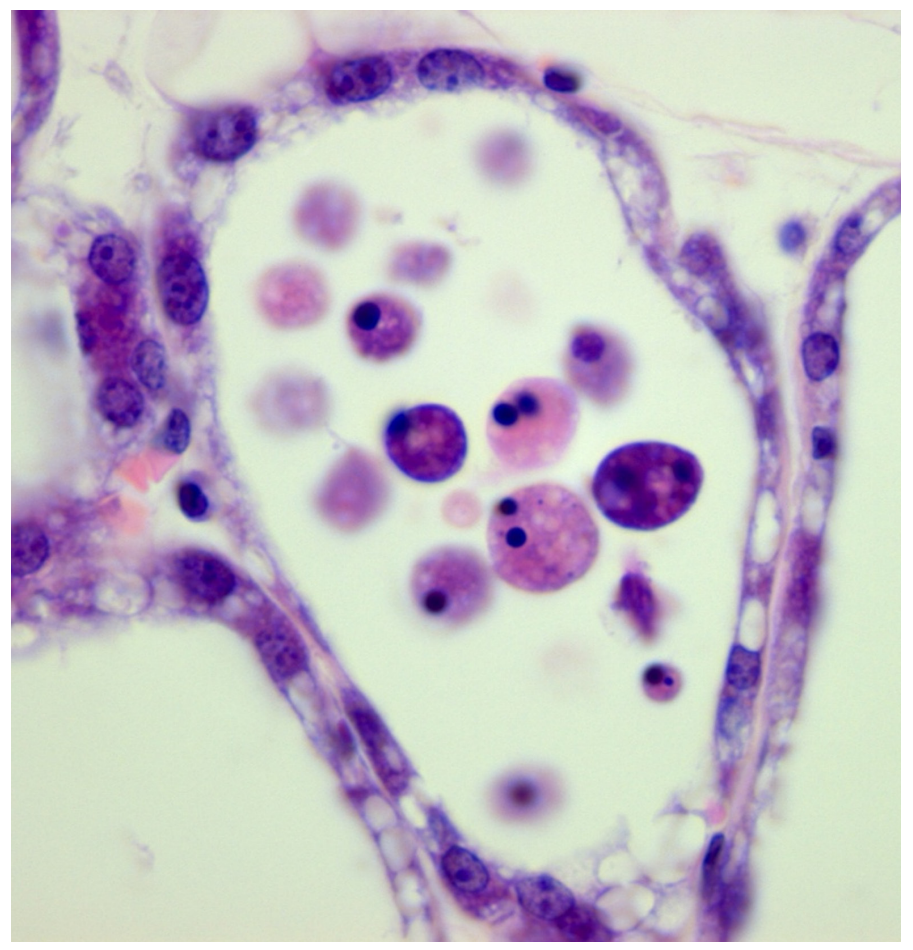

Fig. 1. Cell death during mammary gland involution does not resemble apoptosis. A single alveolus from a 24 h involution mammary gland tissue section showing numerous cells shed into the alveolar lumen. Note the highly condensed nuclei and swollen appearance of the cells with no evidence of membrane blebbing. 


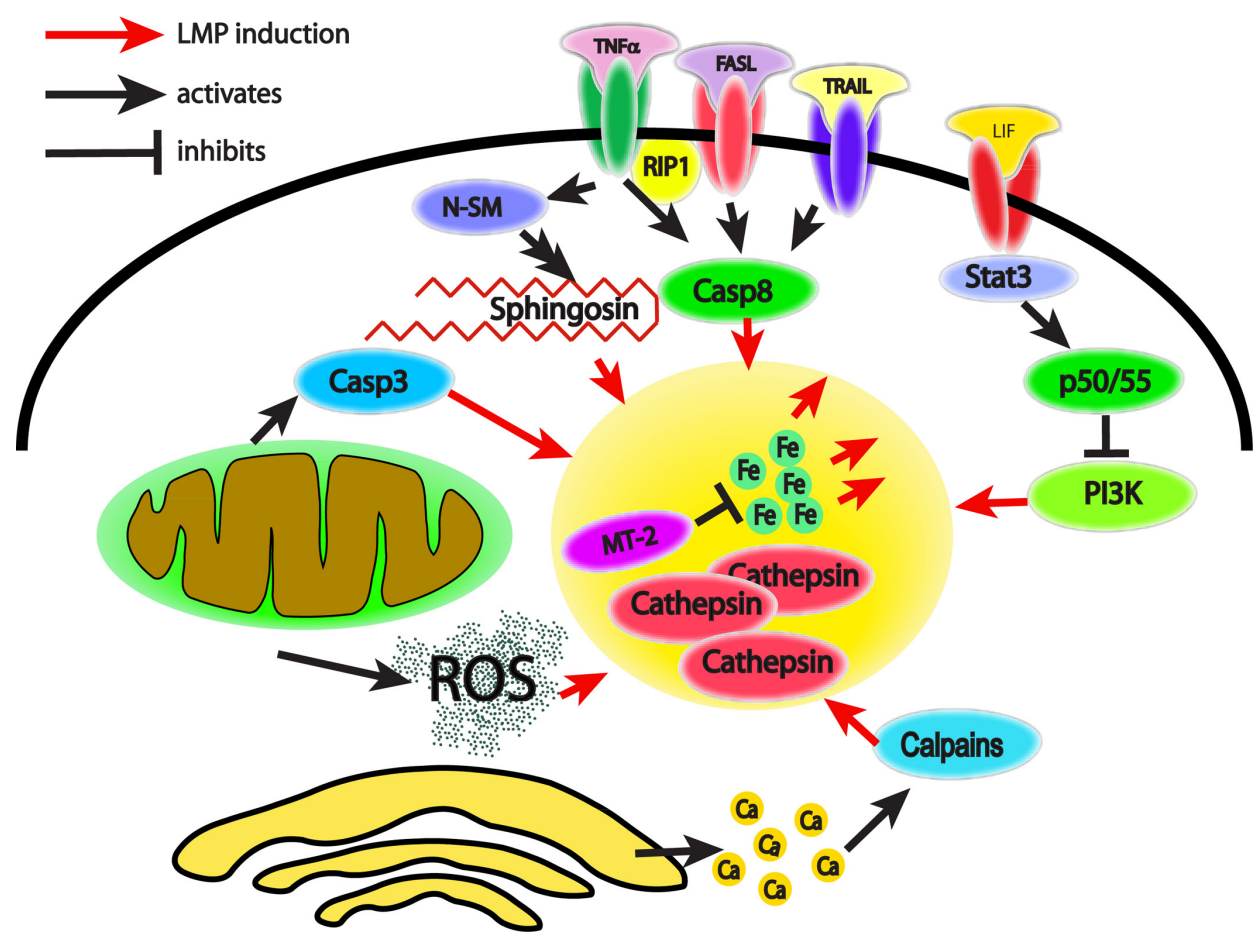

Fig. 2. Inducers of Lysosomal Membrane Permeabilisation (LMP). Schematic overview of selected inducers of $L M P$ relevant to mammary gland involution. $L M P$ can be induced downstream of death receptors either directly or through the involvement of Caspase 8. Furthermore TNF can activate neutral sphingomyelinase, which ultimately leads to the production of sphingosine and LMP. Damaged mitochondria produce ROS and activate caspase 3 , both of which are implicated in LMP. Calcium activated calpains, lysosomal cathepsins and the PI3K pathway can all affect LMP. Metallothionein 2 can protect lysosomes from excessive free iron.

phase but it could be that changes in systemic hormones lead to the induction of the expression of proteases such as MMPs that degrade extracellular matrix (ECM), and serine proteases that activate plasminogen.

The primary source of MMPs is the stromal cells, and expression of MMP-2, MMP-3, MMP-9 and MMP-11 is upregulated during involution. MMPs cleave a variety of substrates such as collagen IV, chemokines and E-cadherin, which will facilitate cell detachment. Thus, cells that have survived first phase involution can be induced to die by anoikis (detachment-induced cell death) provided MMPs are expressed and activated. The corollary of this is that MMPs must be inhibited during first phase involution and this is achieved by TIMPs. The inhibitor of MMP-2, TIMP-3, is of particular importance since involution proceeds more rapidly in TIMP-3 deficient mammary glands and the reversibility of first phase is lost (Fata et al., 2001). Overexpression of TIMP-1, or loss of stromelysin, results in accelerated differentiation of adipocytes, while having no effect on cell death (Alexander et al., 2001). This suggests that MMPs do not directly affect cell death but are primarily involved in remodelling the stromal environment.

\section{Inflammatory signalling and immune cells in involution}

The activation of Stat3 and NF- $\kappa B$ signalling pathways suggests that inflammatory signalling may also be important during involution. This notion is supported by data from the microarray studies mentioned above that identified an immune cascade and acute phase response during involution (Clarkson et al., 2004; Stein et al., 2004). Importantly, both pro- and anti-inflammatory genes are expressed, probably in order to ensure that overt inflammation does not occur. An influx of immune cells has been observed, starting with neutrophils at day 1 involution followed by macrophages, eosinophils, plasma cells and B-lymphocytes around day 4 (Stein et al., 2004). These cells are often found in a peri-ductal location but immune cells have been found in the milk of sheep and cows during involution, suggesting that they can traverse into the lumens of ducts (Tatarczuch et al., 2000).

Phagocytes are critically important to the involution process as mentioned above. In early involution, this role is undertaken by the viable epithelium utilising the same recognition molecules as professional phagocytes. The scavenger receptor, CD14, is strongly induced in involution in a Stat3-dependent manner and mammary epithelial cells have been shown to express calreticulin, CD91 and CD36 (Monks et al., 2005). Engulfment induces production of anti-inflammatory cytokines such as TGF $\beta$ (Monks et al., 2002), essential for ensuring involution proceeds without inflammation.

Expression of acute phase response genes is another characteristic of involution, perhaps not surprisingly as many of these genes are regulated by Stat3 and/or NF-кB. One of these is uterocalin, a lipocalin that induces apoptosis of neutrophils and other leukocytes. Uterocalin could protect mammary epithelial cells from damaging free radicals and proteases released from leukocytes and macrophages. Among the most strikingly upregulated genes are orosomucoids 1 and 2 which act as carriers of basic and neutrally charged lipophilic compounds including steroids and protease inhibitors. Serum amyloid A proteins, the precursors of inflammation-associated reactive amyloidosis, can bind to high density lipoproteins, calcium, laminin and heparin/heparan-sulfate, and have been implicated in inducing leukocyte migration.

\section{Conclusion}

Steady progress has been made in investigating the mechanisms of mammary gland involution. Analyses of changes in gene expression during the involution process have highlighted roles for immune cells and the inflammatory/acute phase responses. A role for mammary epithelia cells as phagocytes has highlighted the plasticity of these cells. Recent insights have been obtained into the mechanism of cell death which will provide the basis for much future research. However, several outstanding questions remain and could be the focus for future work. Is the initiating signal for apoptosis mechanical or biological? How is the transition from the reversible to irreversible phase controlled? How are the stem cells protected from cell death? These are challenging questions 
to address and, despite our progress, we still lack a detailed understanding of the involution process.

\section{Acknowledgements}

PAK is supported by a Trinity College research fellowship.

\section{References}

ALBREKTSEN, G., HEUCH, I., TRETLI, S., and KVALE, G. (1994). Breast cancer incidence before age 55 in relation to parity and age at first and last births: a prospective study of one million Norwegian women. Epidemiology 5: 604-611.

ALEXANDER, C.M., SELVARAJAN, S., MUDGETT, J., and WERB, Z. (2001). Stromelysin-1 regulates adipogenesis during mammary gland involution. J Cell Biol 152: 693-703.

ATABAI, K., FERNANDEZ, R., HUANG, X., UEKI, I., KLINE, A., LI, Y., SADATMANSOORI, S., SMITH-STEINHART, C., ZHU, W., PYTELA, R., ET Al., (2005). Mfge8 is critical for mammary gland remodeling during involution. $\mathrm{Mol} B i \mathrm{O} C$ ell 16: 5528-5537.

BAXTER, F.O., CAME, P.J., ABELL, K., KEDJOUAR, B., HUTH, M., RAJEWSKY, K., PASPARAKIS, M., and WATSON, C.J. (2006). IKKbeta/2 induces TWEAK and apoptosis in mammary epithelial cells. Development 133: 3485-3494.

BRAY, F., MCCARRON, P., and PARKIN, D.M. (2004). The changing global patterns of female breast cancer incidence and mortality. Breast Cancer Res 6: 229-239.

CHAPMAN, R.S., LOURENCO, P.C., TONNER, E., FLINT, D.J., SELBERT, S., TAKEDA, K., AKIRA, S., CLARKE, A.R., and WATSON, C.J. (1999). Suppression of epithelial apoptosis and delayed mammary gland involution in mice with a conditional knockout of Stat3. Genes Dev 13: 2604-2616.

CLARKSON, R.W., WAYLAND, M.T., LEE, J., FREEMAN, T., and WATSON, C.J. (2004). Gene expression profiling of mammary gland development reveals putative roles for death receptors and immune mediators in post-lactational regression. Breast Cancer Res 6, R92-109.

DANIAL, N.N., and KORSMEYER, S.J. (2004). Cell death: critical control points. Cell 116: 205-219.

FATA, J.E., LECO, K.J., VOURA, E.B., YU, H.Y., WATERHOUSE, P., MURPHY, G., MOOREHEAD, R.A., and KHOKHA, R. (2001). Accelerated apoptosis in the Timp-3-deficient mammary gland. J Clin Invest 108: 831-841.

FENG, Z., MARTI, A., JEHN, B., ALTERMATT, H.J., CHICAIZA, G., and JAGGI, R. (1995). Glucocorticoid and progesterone inhibit involution and programmed cell death in the mouse mammary gland. J Cell Biol 131: 1095-1103.

GREEN, K.A., and LUND, L.R. (2005). ECM degrading proteases and tissue remodelling in the mammary gland. Bioessays 27: 894-903.

HANAYAMA, R., and NAGATA, S. (2005). Impaired involution of mammary glands in the absence of milk fat globule EGF factor 8. Proc Natl Acad Sci USA 102: 16886-16891.

HUMPHREYS, R.C., BIERIE, B., ZHAO, L., RAZ, R., LEVY, D., and HENNIGHAUSEN, L. (2002). Deletion of Stat3 blocks mammary gland involution and extends functional competence of the secretory epithelium in the absence of lactogenic stimuli. Endocrinology 143: 3641-3650.

KERR, J.F., WYLLIE, A.H., and CURRIE, A.R. (1972). Apoptosis: a basic biological phenomenon with wide-ranging implications in tissue kinetics. $\mathrm{Br} J$ Cancer 26 : 239-257.

Kreuzaler, P.A., Staniszewska, A.D., Li, W., Omidvar, N., Kedjouar, B., Turkson, J., Poli, V., Flavell, R.A., Clarkson, R.W., and Watson, C.J. (2011) Stat3 controls lysosomal-mediated cell death in vivo. Nat Cell Biol 13: 303-309.

KRITIKOU, E.A., SHARKEY, A., ABELL, K., CAME, P.J., ANDERSON, E., CLARKSON, R.W., and WATSON, C.J. (2003). A dual, non-redundant, role for LIF as a regulator of development and STAT3-mediated cell death in mammary gland. Development 130: 3459-3468.

KROEMER, G., and LEVINE, B. (2008). Autophagic cell death: the story of a misnomer. Nat Rev Mol Cell Biol 9: 1004-1010.

LAMBE, M., HSIEH, C., TRICHOPOULOS, D., EKBOM, A., PAVIA, M., and ADAMI, H.O. (1994). Transient increase in the risk of breast cancer after giving birth. $N$ Engl J Med 331: 5-9.

LI, M., LIU, X., ROBINSON, G., BAR-PELED, U., WAGNER, K.U., YOUNG, W.S., HENNIGHAUSEN, L., and FURTH, P.A. (1997). Mammary-derived signals activate programmed cell death during the first stage of mammary gland involution. Proc Natl Acad Sci USA 94: 3425-3430.

LILLA, J.N., JOSHI, R.V., CRAIK, C.S., and WERB, Z. (2009). Active plasma kallikrein localizes to mast cells and regulates epithelial cell apoptosis, adipocyte differentiation, and stromal remodeling during mammary gland involution. $J$ Biol Chem 284: 13792-13803.

LUND, L.R., ROMER, J., THOMASSET, N., SOLBERG, H., PYKE, C., BISSELL, M.J., DANO, K., and WERB, Z. (1996). Two distinct phases of apoptosis in mammary gland involution: proteinase-independent and -dependent pathways. Development 122: 181-193.

MARTI, A., FENG, Z., ALTERMATT, H.J., and JAGGI, R. (1997). Milk accumulation triggers apoptosis of mammary epithelial cells. Eur J Cell Biol 73: 158-165.

MATSUDA, M., IMAOKA, T., VOMACHKA, A.J., GUDELSKY, G.A., HOU, Z., MISTRY, M., BAILEY, J.P., NIEPORT, K.M., WALTHER, D.J., BADER, M., ET AL., (2004). Serotonin regulates mammary gland development via an autocrine-paracrine loop. Dev Cell 6: 193-203.

MCDANIEL, S.M., RUMER, K.K., BIROC, S.L., METZ, R.P., SINGH, M., PORTER, W., and SCHEDIN, P. (2006). Remodeling of the mammary microenvironment after lactation promotes breast tumor cell metastasis. Am J Pathol 168: 608-620.

MELINO, G., KNIGHT, R.A., and NICOTERA, P. (2005). How many ways to die? How many different models of cell death? Cell Death Differ 12 Suppl 2: 1457-1462.

MONKS, J., GESKE, F.J., LEHMAN, L., and FADOK, V.A. (2002). Do inflammatory cells participate in mammary gland involution? J Mammary Gland Biol Neoplasia 7: 163-176.

MONKS, J., ROSNER, D., GESKE, F.J., LEHMAN, L., HANSON, L., NEVILLE, M.C., and FADOK, V.A. (2005). Epithelial cells as phagocytes: apoptotic epithelial cells are engulfed by mammary alveolar epithelial cells and repress inflammatory mediator release. Cell Death Differ 12: 107-114.

NGUYEN, A.V., and POLLARD, J.W. (2000). Transforming growth factor beta3 induces cell death during the first stage of mammary gland involution. Development 127: 3107-3118.

OFTEDAL, O.T. (2002). The mammary gland and its origin during synapsid evolution. J Mammary Gland Biol Neoplasia 7: 225-252.

OVERHOLTZER, M., MAILLEUX, A.A., MOUNEIMNE, G., NORMAND, G., SCHNITT, S.J., KING, R.W., CIBAS, E.S., and BRUGGE, J.S. (2007). A nonapoptotic cell death process, entosis, that occurs by cell-in-cell invasion. Cell 131: 966-979.

QUAGLINO, A., SALIERNO, M., PELLEGROTTI, J., RUBINSTEIN, N., and KORDON, E.C. (2009). Mechanical strain induces involution-associated events in mammary epithelial cells. BMC Cell Biol 10: 55.

SCHERE-LEVY, C., BUGGIANO, V., QUAGLINO, A., GATTELLI, A., CIRIO, M.C., PIAZZON, I., VANZULLI, S., and KORDON, E.C. (2003). Leukemia inhibitory factor induces apoptosis of the mammary epithelial cells and participates in mouse mammary gland involution. Exp Cell Res 282: 35-47.

SCHORR, K., LI, M., BAR-PELED, U., LEWIS, A., HEREDIA, A., LEWIS, B., KNUDSON, C.M., KORSMEYER, S.J., JAGER, R., WEIHER, H., et al., (1999). Gain of $\mathrm{Bcl}-2$ is more potent than bax loss in regulating mammary epithelial cell survival in vivo. Cancer Res 59: 2541-2545.

SHARP, J.A., CANE, K.N., LEFEVRE, C., ARNOULD, J.P., and NICHOLAS, K.R. (2006). Fur seal adaptations to lactation: insights into mammary gland function. Curr Top Dev Biol 72: 275-308.

SOHN, B.H., MOON, H.B., KIM, T.Y., KANG, H.S., BAE, Y.S., LEE, K.K., and KIM S.J. (2001). Interleukin-10 up-regulates tumour-necrosis-factor-alpha-related apoptosis-inducing ligand (TRAIL) gene expression in mammary epithelial cells at the involution stage. Biochem J 360: 31-38.

SONG, J., SAPI, E., BROWN, W., NILSEN, J., TARTARO, K., KACINSKI, B.M., CRAFT, J., NAFTOLIN, F., and MOR, G. (2000). Roles of Fas and Fas ligand during mammary gland remodeling. J Clin Invest 106: 1209-1220.

STEIN, T., MORRIS, J.S., DAVIES, C.R., WEBER-HALL, S.J., DUFFY, M.A., HEATH, V.J., BELL, A.K., FERRIER, R.K., SANDILANDS, G.P., and GUSTERSON, B.A. (2004). Involution of the mouse mammary gland is associated with an immune cascade and an acute-phase response, involving LBP, CD14 and STAT3. Breast Cancer Res 6, R75-91.

TATARCZUCH, L., PHILIP, C., BISCHOF, R., and LEE, C.S. (2000). Leucocyte phenotypes in involuting and fully involuted mammary glandular tissues and secretions of sheep. J Anat 196 (Pt 3), 313-326. 
THANGARAJU, M., RUdeliUS, M., BIERIE, B., RAFFELD, M., SHARAN, S., HENNIGHAUSEN, L., HUANG, A.M., and STERNECK, E. (2005). C/EBPdelta is a crucial regulator of pro-apoptotic gene expression during mammary gland involution. Development 132: 4675-4685.

VANHOUTEN, J., SULLIVAN, C., BAZINET, C., RYOO, T., CAMP, R., RIMM, D.L., CHUNG, G., and WYSOLMERSKI, J. (2010) PMCA2 regulates apoptosis during mammary gland involution and predicts outcome in breast cancer. Proc Natl Acad Sci USA 107: 11405-11410.
WALTON, K.D., WAGNER, K.U., RUCKER, E.B., 3RD, SHILLINGFORD, J.M., MIYOSHI, K., and HENNIGHAUSEN, L. (2001). Conditional deletion of the bcl-x gene from mouse mammary epithelium results in accelerated apoptosis during involution but does not compromise cell function during lactation. Mech Dev 109: 281-293.

ZETTL, K.S., SJAASTAD, M.D., RISKIN, P.M., PARRY, G., MACHEN, T.E., and FIRESTONE, G.L. (1992). Glucocorticoid-induced formation of tight junctions in mouse mammary epithelial cells in vitro. Proc Natl Acad Sci USA 89: 9069-9073.

\section{Further Related Reading, published previously in the Int. J. Dev. Biol.}

The interplay between macrophages and angiogenesis in development, tissue injury and regeneration Silvia Nucera, Daniela Biziato and Michele De Palma Int. J. Dev. Biol. (2011) 55: 495-503

The role of angiogenic growth factors in organogenesis Enrico Crivellato Int. J. Dev. Biol. (2011) 55: 365-375

Casein kinase I epsilon somatic mutations found in breast cancer cause overgrowth in Drosophila Tomas Dolezal, Katerina Kucerova, Jana Neuhold and Peter J. Bryant Int. J. Dev. Biol. (2010) 54: 1419-1424

Both jnk and apoptosis pathways regulate growth and terminalia rotation during Drosophila genital disc development Sergio Benitez, Claudia Sosa, Nicolás Tomasini and Ana Macías Int. J. Dev. Biol. (2010) 54: 643-653

Epithelial-Mesenchymal Transitions in development and disease: old views and new perspectives M. Angela Nieto

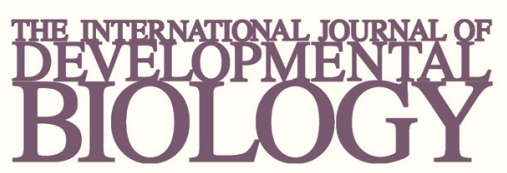

Volume 54 Nos. 6/7
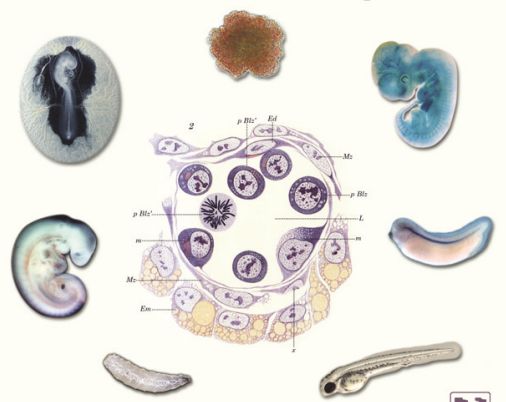

Developmental Hematopoiesis

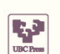

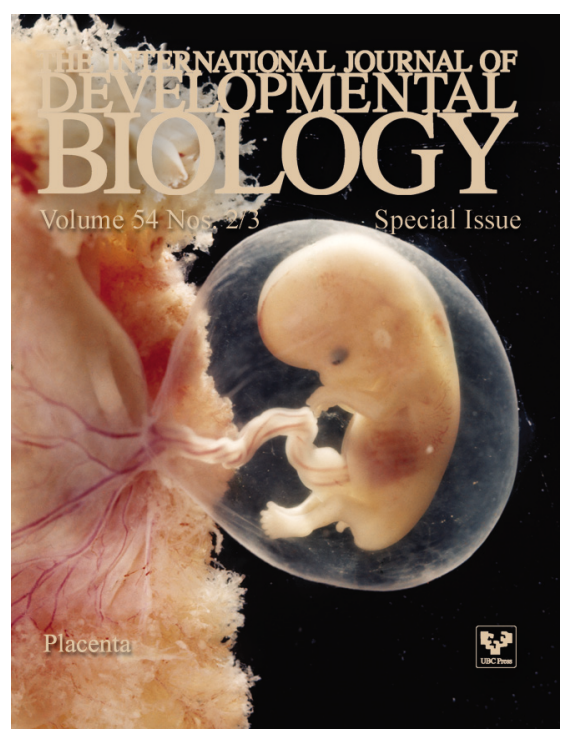

